\title{
POLA KONSUMSI IKAN LAUT DAN FAKTOR-FAKTOR YANG MEMENGARUHI KONSUMSI IKAN LAUT OLEH IBU HAMIL DI KECAMATAN KOTAAGUNG KABUPATEN TANGGAMUS
}

\author{
(Marine Fish Dietary Pattern and Factors Affecting Consumption of Marine Fish by Pregnant Women \\ in Kotaagung Subdistrict of Tanggamus District)
}

Bagus Lujeng Pangestu, Yaktiworo Indriani, Lina Marlina

Jurusan Agribisnis, Fakultas Pertanian, Universitas Lampung, Jl. Prof. Dr. Soemantri Brojonegoro No. 1, Bandar Lampung, 35145, e-mail: yaktiworo.indriani@fp.unila.ac.id

\begin{abstract}
This study aims to analyze dietary patterns and factors that affect consumption of marine fish by pregnant women in Kotaagung Subdistrict of Tanggamus District. Respondents are 42 women at second and third trimester pregnancies who are recruited voluntarily. Data are analyzed descriptively using Multiattribute Fishbein and multiple linear regressions. The results showed that the consumption patterns of marine fish of pregnant women were illustrated by type of fish consumed, the amount of consumption, frequencies and locations of purchase. The types of fish consumed were cob, flying fish, anchovy, squid, bloated, and blue marlin. The dominant fish consumed by respondents was cob. The average amount of marine fish consumption by pregnant women was 42.12 grams/week and considered very low. The average consumption of protein was 6.02 grams (1.40\%AKE) per day and it was calculated that the maximum desireable dietary pattern (DDP) score for animal food was only 5.60 out of 24 of DDP ideal score. Purchase frequencies of marine fish were once to four times a week. Purchase locations were traditional markets and traveling traders. The factors that influenced the consumption of marine fish were prices of marine fish, pond fish, chicken, and tempeh, income, number of family members, and education.
\end{abstract}

Key words: dietary pattern, marine fish, pregnant women.

\section{PENDAHULUAN}

Kabupaten Tanggamus menjadi lumbung perikanan tangkap tertinggi kelima di Provinsi Lampung di bawah Kabupaten Lampung Timur, Bandar Lampung, Lampung Selatan, dan Tulang Bawang. Kabupaten Tanggamus mampu memproduksi sebanyak 18.984 ton ikan per tahun. Jenis Ikan yang menjadi andalan adalah nibung (blue marlin), tongkol, tenggiri, kembung, dan simba. Kabupaten Tanggamus mengalami kenaikan produksi ikan laut yang signifikan pada 2015-2016 (BPS Provinsi Lampung 2017).

Prestasi Kabupaten Tanggamus dalam hal produksi ikan laut tidak selaras dengan tingkat konsumsinya. Konsumsi ikan laut Kabupaten Tanggamus tergolong masih rendah. Konsumsi ikan laut secara keseluruhan di Kabupaten Tanggamus pada tahun 2017 hanya mencapai angka $21,87 \mathrm{~kg}$ per kapita per tahun, sementara target pemerintah adalah $50,80 \mathrm{~kg}$ per kapita per tahun (DKP Kabupaten Tanggamus 2018).

Kabupaten Tanggamus merupakan daerah dengan angka kelahiran Berat Badan Lahir Rendah
(BBLR) tertinggi keenam di Provinsi Lampung. Angka BBLR di Kabupaten Tanggamus mencapai angka 2,78 persen dari total 11.200 kelahiran selama 2017. Kualitas sumber daya manusia akan sangat ditentukan oleh anak-anak yang dilahirkan dan kualitas bayi yang dilahirkan akan sangat dipengaruhi oleh asupan zat gizi ibu selama kehamilan. Asupan gizi sangat menentukan kesehatan ibu hamil dan janin yang dikandungnya. Kebutuhan gizi pada fase kehamilan akan meningkat 15 persen dibanding kebutuhan wanita normal. Kekurangan gizi selama kehamilan akan menimbulkan masalah. Dampak yang akan timbul adalah banyak terjadinya kasus BBLR (Rusilanti 2006).

Hebbeln (2008) menyatakan bahwa ikan mengandung DHA (Docosahecanoic Acid) dapat mendukung pertumbuhan optimal saraf janin selama kehamilan. Ibu hamil yang mengonsumsi ikan pada fase kehamilan diharapkan mampu melahirkan anak yang sehat dan cerdas. Widyakarya Pangan dan Gizi XI (2018), menetapkan angka kecukupan protein (AKP) adalah sebesar 57 gram per kapita per hari. Angka Kecukupan Protein (AKP) yang telah ditetapkan 
diharapkan mampu terpenuhi, agar kebutuhan gizi dan protein penduduk Indonesia sesuai dengan standar kesehatan.

Hasil penelitian Riawa, Yulinda dan Darwis (2016) menyatakan bahwa faktor-faktor yang memengaruhi seseorang dalam mengonsumsi ikan laut untuk pemenuhan gizinya adalah pendapatan keluarga, jumlah anggota keluarga, harga dan daerah asal. Berdasarkan uraian tersebut dilakukan penelitian dengan tujuan untuk menganalisis pola konsumsi ikan laut ibu hamil dan menganalisis faktor-faktor yang memengaruhi konsumsi ikan laut pada ibu hamil di Kabupaten Tanggamus.

\section{METODE PENELITIAN}

Penelitian ini menggunakan metode survai. Lokasi penelitian dipilih secara sengaja (purposive). Terdapat tiga pekon dan kelurahan yang dipilih sebagai lokasi penelitian dari total 16 pekon dan kelurahan. Tiga pekon dan kelurahan yang terpilih adalah Kelurahan Baros, Pekon Terbaya dan Pekon Kusa. Lokasi dipilih berdasarkan pertimbangan jumlah kasus berat bayi lahir rendah (BBLR) tertinggi yang terjadi selama kurun waktu 20172018, yaitu 12 kasus di Kelurahan Baros, serta Pekon Kusa dan Pekon Terbaya masing-masing terdapat 7 kasus.

Jenis data yang digunakan dalam penelitian ini adalah data primer dan sekunder. Data primer merupakan data yang dikumpulkan melalui wawancara langsung menggunakan kuisioner meliputi pola konsumsi ikan laut ibu hamil dan faktor yang memengaruhi ibu hamil dalam mengonsumsi ikan laut. Data sekunder adalah data yang diperoleh dari lembaga-lembaga yang terkait dengan penelitian ini. Data sekunder yang digunakan antara lain data produksi perikanan tangkap di Provinsi Lampung, data berat badan lahir rendah dan gizi buruk di Provinsi Lampung serta data-data lain yang berhubungan dengan tujuan penelitian.

Pengambilan data dilakukan pada bulan FebruariMaret 2019. Menurut hasil prasurvei yang dilakukan, populasi ibu hamil usia trimester dua dan trimester tiga pada ketiga lokasi tersebut adalah 108 ibu hamil. Responden ibu hamil dipilih menggunakan teknik cluster sampling. Teknik cluster digunakan untuk memilih sampel berdasarkan pada kelompok, daerah, atau kelompok subjek yang secara alami berkumpul bersama (Margono 2004). Penentuan jumlah sampel mengacu pada rumus Isaac dan Michael dalam Ismail (2018), sebagai berikut.

$\mathrm{S}=\frac{\lambda^{2} \mathrm{NPQ}}{\mathrm{d}^{2}(\mathrm{~N}-1)+\lambda^{2} \mathrm{PQ}}$

Keterangan :

$\mathrm{S}$ = Jumlah sampel

$\lambda^{2}=$ Tingkat kepercayaan $(90 \%=1,645)$

$\mathrm{N}=$ Jumlah populasi (108 ibu hamil)

$\mathrm{d}=$ Derajat penyimpangan $(10 \%=0,10)$

$\mathrm{P}=$ Peluang benar $(0,50)$

$\mathrm{Q}=$ Peluang salah $(0,50)$

Berdasarkan hasil perhitungan dengan menggunakan rumus persamaan 1 diperoleh jumlah sampel sebanyak 42 orang. Alokasi proporsi sampel yang telah didapat untuk masingmasing yaitu Kelurahan Baros 21 ibu hamil, Pekon Kusa 13 ibu hamil dan Pekon Terbaya 8 ibu hamil. Dengan demikian, jumlah responden dalam penelitian ini sebanyak 42 ibu hamil.

Analisis pola konsumsi ikan dilakukan secara deskriptif dengan cara mendeskripsikan pola konsumsi ibu hamil yang meliputi jumlah ikan yang dikonsumsi, tempat pembelian yang pada penelitian ini dibedakan menjadi pedagang keliling dan pasar tradisional, frekuensi pembelian serta jenis ikan yang dibeli. Data yang diperoleh dibandingkan dengan menggunakan tabel skor Pola Pangan Harapan (PPH) untuk melihat berapakah sumbangan protein hewani dari ikan laut yang dikonsumsi ibu hamil.

Analisis faktor-faktor yang memengaruhi konsumsi ikan ibu hamil menggunakan analisis regresi linier berganda dengan melihat pengaruh antara suatu variabel dependen dan beberapa variabel independen (Gujarati 2003). Secara matematis dirumuskan sebagai berikut.

$\begin{aligned} \mathrm{Y}= & \mathrm{a} \mathrm{X}_{1}^{\mathrm{b} 1} \mathrm{X}_{2}^{\mathrm{b} 2} \mathrm{X}_{3}^{\mathrm{b} 3} \mathrm{X}_{4}^{\mathrm{b} 4} \mathrm{X}_{5}^{\mathrm{b} 5} \mathrm{X}_{6}^{\mathrm{b} 6} \mathrm{X}_{7}^{\mathrm{b} 7} \mathrm{X}_{8}^{\mathrm{b} 8} \mathrm{X}_{9}^{\mathrm{b} 9} \mathrm{X}_{10}^{\mathrm{b} 10} \\ & \mathrm{D}_{1}^{\mathrm{d} 1} \mathrm{D}_{2}^{\mathrm{d} 2} \mathrm{e} \ldots \ldots \ldots \ldots \ldots \ldots \ldots \ldots \ldots \ldots \ldots \ldots \ldots \ldots \ldots \ldots \ldots \ldots \ldots \ldots \ldots \ldots \ldots \ldots\end{aligned}$

Keterangan:

$\mathrm{Y}=$ Konsumsi ikan laut (gram protein/hari)

$\mathrm{a}=$ Konstanta/intercept

bi $=$ Besaran yang diduga

$\mathrm{u} \quad=$ Kesalahan (disturbance term)

$\mathrm{e} \quad=$ Logaritma natural, $\mathrm{e}=2,718$

$\mathrm{X}_{1}=$ Harga ikan laut (Rp/gram protein)

$\mathrm{X}_{2}=$ Harga ikan tawar (Rp/gram protein)

$\mathrm{X}_{3}=$ Harga ayam (Rp/gram protein)

$\mathrm{X}_{4}=$ Harga telur (Rp/gram protein)

$\mathrm{X}_{5}=$ Harga tempe (Rp/gram protein) 
$\mathrm{X}_{6}=$ Harga tahu (Rp/protein)

$\mathrm{X}_{7}=$ Harga ikan asin (Rp/protein)

$\mathrm{X}_{8}=$ Pendapatan $(\mathrm{Rp} / \mathrm{bulan})$

$\mathrm{X}_{9}=$ Anggota rumah tangga (orang)

$\mathrm{X}_{10}=$ Selera (MSI)

$\mathrm{D}_{1}=$ Dummy pendidikan, D1= Pendidikan

Tinggi, D0 = Pendidikan rendah

$\mathrm{D}_{2}=$ Dummy lokasi penelitian $\mathrm{D} 1=$ pedagang

keliling, D2 = pasar tradisional

Menurut Ghozali (2009), model yang baik adalah model yang sudah diuji masalah regresinya, yaitu uji Multikolinearitas, Heteroskedastisitas, dan Autokorelasi. Model lain yang terbaik dipilih dari koefisien determinasi yang telah disesuaikan $\left(\mathrm{R}^{2}\right.$ adjusted), pengujian variabel bebas cara simultan ( $\mathrm{F}_{\text {hitung }}$ ) dan pengujian variabel bebas secara parsial ( $\mathrm{t}_{\text {hitung }}$ ) yang mendekati angka satu.

Persamaan dengan model regresi linier berganda perlu memenuhi beberapa asumsi, agar kondisi model tersebut Ordinary Least Square (OLS). Pengujian dimaksudkan agar persamaan regresi yang dihasilkan supaya valid, jika digunakan untuk memprediksi. Cara mendeteksi masalah multikolinearitas dengan melihat nilai VIF (Variance Inflation Estimate). Jika nilai VIF $<10$ berarti variabel tidak mengalami multikolinearitas.

Uji statistik yang digunakan untuk menguji heteroskedastisitas yaitu uji white heterokedasticity dengan aplikasi Eviews 8. Apabila menghasilkan Chi Square > 0,05 maka tidak terjadi masalah heteroskedastisitas. Uji autokorelasi digunakan untuk mengetahui apakah dalam suatu model regresi linear ada korelasi antara kesalahan pengganggu dengan kesalahan sebelumnya dengan uji Durbin Watson. Kritik pengujiannya adalah jika du $<\mathrm{d}<4 \pm$ du, maka Ho ditolak yang berarti tidak ada autokorelasi baik positif maupun negatif.

\section{HASIL DAN PEMBAHASAN}

\section{Karakteristik Responden}

Kategori umur responden dikelompokkan menjadi muda (22-27 tahun), sedang (28-33 tahun) dan tua (34-40 tahun). Jumlah responden kategori umur sedang sebanyak 16 orang serta tua dan muda masing-masing berjumlah 13 orang. Responden adalah ibu hamil pada usia kehamilan trimester dua (14-27 minggu) dan trimester tiga (28-41 minggu). Jumlah responden trimester dua sebanyak 24 orang dan trimester tiga 18 orang. Mayoritas responden merupakan lulusan Sekolah Menengah Atas (SMA), yaitu sebanyak 24 orang responden.
Responden pada penelitian ini mayoritas bekerja sebagai Ibu Rumah Tangga (IRT), yaitu sebanyak 32 orang.

\section{Pola Konsumsi}

Tempat pembelian ikan laut adalah di pasar tradisional dan pedagang keliling. Sebanyak 23 orang responden melakukan pembelian ikan laut di pasar tradisional dan 19 orang melalui pedagang keliling. Responden memilih membeli ikan laut di pasar tradisional, karena jarak rumah dengan pasar tradisional yang tidak jauh. Pertimbangan lainnya adalah dengan membeli di pasar tradisional diharapkan mampu memperoleh harga yang lebih murah dan ikan lebih terjamin kualitasnya. Responden yang memilih membeli ikan kepada pedagang keliling, karena sungkan untuk pergi ke pasar. Kondisi tubuh yang sedang berada pada fase kehamilan membuat responden memilih untuk lebih banyak istirahat di rumah dan menunggu pedagang keliling singgah ke rumah mereka.

Terdapat 6 jenis ikan laut yang dikonsumsi pada penelitian ini. Jenis-jenis ikan laut yang dikonsumsi tersebut adalah tongkol, layang, teri, cumi, kembung, dan nibung. Mayoritas responden (28 orang) mengonsumsi dua jenis ikan laut, 10 orang responden mengonsumsi satu jenis, dan 4 orang responden lainnya mengonsumi tiga jenis ikan setiap minggu.

Tiga jenis ikan laut yang dikonsumsi terdiri dari cumi, kembung, nibung, atau tongkol, teri, kembung, atau tongkol, teri, cumi, atau tongkol, layang, nibung. Satu jenis ikan yang hanya dikonsumsi setiap minggu adalah tongkol, layang dan cumi. Tidak ada satu orang responden yang mengonsumsi lebih dari tiga jenis ikan laut setiap minggu, dikarenakan responden menyelingi menu makannya dengan beberapa bahan pangan lain seperti ikan air tawar, daging ayam, telur ayam, tahu, tempe, dan ikan asin.

Frekuensi pembelian ikan laut oleh responden cukup beragam. Frekuensi pembelian paling banyak adalah 4 kali dan paling sedikit adalah 1 kali per minggu. Responden yang melakukan pembelian satu kali biasanya membeli lebih dari satu jenis ikan laut. Kondisi kehamilan membuat ibu hamil lebih memilih membeli ikan kemudian disimpan di lemari pendingin. Jumlah konsumsi ikan laut dalam \%AKP oleh ibu hamil per hari disajikan pada Tabel 1. 
Tabel 1. Jumlah konsumsi protein hewani ikan laut dalam \%AKP oleh ibu hamil per hari

\begin{tabular}{lrrr}
\hline & $\begin{array}{c}\text { Konsumsi Protein } \\
\text { (gram/hari) }\end{array}$ & $\begin{array}{c}\text { AKP } \\
\text { (gram/hari) }\end{array}$ & \multicolumn{1}{c}{ AKP } \\
\hline Rata-rata & 6,02 & 76,52 & 8,00 \\
Max & 18,02 & 103,93 & 22,00 \\
Min & 1,38 & 60,18 & 2,00 \\
\hline
\end{tabular}

Tabel 1 menunjukkan bahwa rata-rata tingkat konsumsi protein hewani yang berasal dari ikan laut oleh ibu hamil di Kecamatan Kotaagung mencapai angka 6,02 gram protein per hari. Ratarata standar Angka Kecukupan Protein (AKP) ibu hamil ada pada angka 76,52 gram protein per hari.

Tingkat konsumsi protein hewani pada fase kehamilan seharusnya lebih ditingkatkan untuk menjaga kesehatan ibu dan janin. Ikan laut memiliki kandungan asam lemak omega-3 dan folat yang akan digunakan janin untuk membangun perkembangan otak yang sehat dan cerdas pada anak. Rendahnya tingkat konsumsi ikan laut sebagai sumber protein hewani selama kehamilan menyebabkan masih tingginya angka BBLR di Kecamatan Kotaagung Kabupaten Tanggamus. Hal lain yang memengaruhi rendahnya tingkat konsumsi ikan laut oleh responden adalah gangguan selera makan, karena gejala klinik seperti mual dan lain sebagainya.

Berdasarkan hasil dari Widyakarya Nasional Pangan dan Gizi XI (2018), telah disepakati bahwa rekomendasi ilmiah terkait dengan AKG rata-rata energi 2100 kkal dan Angka Kecukupan Protein (AKP) 57 gram/kapita/hari. Pemerintah Kabupaten Tanggamus harus lebih gencar melakukan peningkatan minat konsumsi ikan laut masyarakatnya. Berbagai upaya yang dapat ditempuh adalah dengan mengadakan gerakan gemar makan ikan serta mengampanyekan dan mensosialisasikan manfaat konsumsi ikan bagi kesehatan tubuh. Hal ini diharapkan mampu mempebaiki tingkat konsumsi protein hewani di Kecamatan Kotaagung Kabupaten Tanggamus, sehingga mampu mencapai AKP yang telah ditetapkan berdasarkan WNPG XI.

Jumlah energi dari ikan laut yang dikonsumsi oleh ibu hamil selama fase kehamilan dibandingkan dengan skor PPH (Pola Pangan Harapan) ideal yang berasal dari golongan pangan hewani. Jumlah asupan energi ikan laut dalam \%AKE oleh ibu hamil disajikan pada Tabel 2.
Tabel 2. Jumlah konsumsi energi dari ikan laut dan pangan hewani lain oleh ibu hamil dibandingkan dengan Pola Pangan Harapan (PPH)

\begin{tabular}{|c|c|c|c|c|}
\hline \multicolumn{5}{|c|}{ Ikan Laut } \\
\hline & $\begin{array}{c}\text { Energi } \\
\text { (kkal/kapita) }\end{array}$ & $\begin{array}{l}\text { AKE } \\
\text { (kkal) }\end{array}$ & $\begin{array}{c}\% \\
\mathrm{AKE}\end{array}$ & $\mathrm{PPH}$ \\
\hline Rataan & 33,16 & $2.486,38$ & 1,40 & 2,70 \\
\hline Max & 72,43 & $3.633,33$ & 2,80 & 5,60 \\
\hline Min & 6,43 & $1.827,27$ & 0,30 & 0,60 \\
\hline \multicolumn{5}{|c|}{ Golongan Hewani Lain } \\
\hline & $\begin{array}{c}\text { Energi } \\
\text { (kkal/individu) }\end{array}$ & $\begin{array}{l}\text { AKE } \\
\text { (kkal) }\end{array}$ & $\begin{array}{c}\% \\
\mathrm{AKE}\end{array}$ & $\mathrm{PPH}$ \\
\hline Rataan & 146,66 & $2.486,38$ & 5,80 & 11,70 \\
\hline Max & 314,40 & $3.633,33$ & 11,60 & 23,20 \\
\hline Min & 0,00 & $1.827,27$ & 0,00 & 0,00 \\
\hline \multicolumn{5}{|c|}{ \%AKE Ikan Laut dan Golongan Hewani Lain } \\
\hline & & & $\begin{array}{c}\% \\
\text { AKE }\end{array}$ & PPH \\
\hline Rataan & & & 7,20 & 14,40 \\
\hline Max & & & 12,90 & 25,80 \\
\hline Min & & & 1,90 & 3,80 \\
\hline
\end{tabular}

Tabel 2 menunjukkan bahwa sumbangan energi yang berasal dari konsumsi ikan laut oleh ibu hamil masih sangat rendah. Rata-rata konsumsi energi hanya mencapai angka 33,16 kkal/kapita/ hari. Diperoleh \%AKE tertinggi hanya sebesar 2,80 persen atau hanya bernilai 5,60 pada skor PPH ideal untuk golongan pangan hewani dan ratarata konsumsi energi ikan laut oleh ibu hamil sebesar 1,40 persen atau menyumbangkan 2,70 pada skor PPH ideal untuk golongan pangan hewani.

Konsumsi golongan pangan hewani selain ikan laut seperti ikan tawar, ayam, telur, dan ikan asin dapat meningkatkan konsumsi energi atau \%AKE tiap individu. Peningkatan \%AKE ikan laut dan golongan hewani lain secara otomatis juga meningkatkan skor PPH untuk konsumsi energi golongan pangan hewani. Konsumsi pangan hewani selain ikan laut ternyata menyumbangkan energi yang jauh lebih besar yaitu dengan rata-rata 5,80 persen.

Penambahan energi dari golongan hewani lain membuat skor PPH masing-masing individu meningkat. Total konsumsi energi ikan laut dan golongan hewani lain menyumbangkan 14,40 pada Skor PPH ideal untuk golongan pangan hewani. Hal ini masih jauh di bawah skor ideal yang ditetapkan, skor PPH untuk golongan pangan hewani sebesar 24,00. Meskipun demikian, terdapat beberapa responden yang mampu melampaui skor ideal PPH dengan memperoleh 
skor 25,80. Responden yang memperoleh skor PPH yang terendah hanya memperoleh 3,80 dari 24,00 skor PPH ideal golongan pangan hewani.

\section{Faktor-faktor yang Memengaruhi Konsumsi Ikan Laut}

Faktor-faktor yang memengaruhi konsumsi ikan laut di Kecamatan Kotaagung Kabupaten Tanggamus dianalisis menggunakan regresi linier berganda. Hasil pengolahan data menunjukkan bahwa semua variabel memiliki nilai toleransi mendekati angka 1 dan nilai VIF (Varian Inflation Factor) <10. Menurut Ghozali (2009), suatu model regresi dikatakan bebas dari masalah multikolinearitas bila nilai VIF diantara angka 1 sampai 10 dan nilai toleransi mendakati angka 1 . Hal tersebut menunjukkan model regresi yang diajukan bebas dari masalah multikolinearitas.

Hasil uji heteroskedastisitas menggunakan uji White menunjukkan bahwa nilai probability chisquare adalah 0,083. Menurut Gujarati dan Porter (2010), nilai probability chi-square yang lebih besar dari $5 \%(0,05)$ berarti tidak terdapat gejala heteroskedastisitas. Hasil uji autokorelasi digunakan untuk mengetahui ada atau tidak penyimpangan asumsi klasik autokorelasi. Setelah dilakuan uji menggunakan statistik $d$ Durbin Watson, angka 2,40 berada pada daerah "d". Artinya tidak ada masalah autokolerasi pada persamaan regresi yang diajukan.

Analisis faktor-faktor yang memengaruhi konsumsi ikan oleh Ibu hamil menggunakan analisis regresi linier berganda. Diduga konsumsi ikan laut pada ibu hamil dipengaruhi oleh harga ikan laut, harga ikan tawar, harga pangan lain (ayam, telur, tempe, tahu dan ikan asin), selera, pendapatan rumah tangga, jumlah anggota rumah tangga, pendidikan ibu, dan lokasi pembelian. Hasil regresi faktor-faktor yang memengaruhi konsumsi ikan laut di Kecamatan Kotaagung Kabupaten Tanggamus disajikan pada Tabel 3.

Data pada Tabel 3 menunjukkan bahwa hasil uji regresi memiliki nilai $R$ square sebesar 0,94 , artinya sebesar 94,00 persen variasi konsumsi ikan laut dapat dijelaskan oleh variabel bebas yang ada di dalam model yaitu harga ikan laut, harga ikan tawar, harga ayam, harga telur, harga tempe, harga tahu, harga ikan asin, pendapatan RT, jumlah anggota rumah tangga, selera, pendidikan, dan lokasi pembelian, sedangkan sisanya sebesar 6,00 persen dijelaskan oleh variabel lain yang tidak dimasukan ke dalam model.
Tabel 3. Hasil regresi faktor-faktor yang memengaruhi konsumsi ikan laut oleh ibu hamil

\begin{tabular}{|c|c|c|c|}
\hline Variabel & t-hitung & $\begin{array}{c}\text { Koef. } \\
\text { Regresi }\end{array}$ & Sig. \\
\hline Konstanta & $-10,18$ & $-8,35$ & 0,00 \\
\hline Harga Ikan Laut $\left(\mathrm{X}_{1}\right)$ & $-2,23$ & $-0,23 *$ & 0,03 \\
\hline Harga Ikan Tawar( $\left.\mathrm{X}_{2}\right)$ & $-2,49$ & $-0,01 *$ & 0,02 \\
\hline Harga Ayam (X3) & $-2,45$ & $-0,01 *$ & 0,02 \\
\hline Harga Telur $\left(X_{4}\right)$ & $-1,44$ & $-0,01$ & 0,16 \\
\hline Harga Tempe $\left(\mathrm{X}_{5}\right)$ & $-2,19$ & $-0,02 *$ & 0,04 \\
\hline Harga Tahu $\left.\mathrm{X}_{6}\right)$ & $-0,34$ & $-0,00$ & 0,73 \\
\hline Harga Ikan Asin $\left(\mathrm{X}_{7}\right)$ & 1,25 & 0,00 & 0,22 \\
\hline Pendapatan RT (X8) & 18,04 & $0,82 * *$ & 0,00 \\
\hline Jumlah Anggota Keluarga $\left(\mathrm{X}_{9}\right)$ & 4,73 & $0,53 * *$ & 0,00 \\
\hline Selera $\left(\mathrm{X}_{10}\right)$ & $-0,22$ & $-0,02$ & 0,83 \\
\hline Pendidikan $\left(D_{1}\right)$ & 3,51 & $0,24 * *$ & 0,00 \\
\hline Lokasi Pembelian $\left(\mathrm{D}_{2}\right)$ & $-0,52$ & $-0,03$ & 0,60 \\
\hline F-hitung & & 37,61 & 0,00 \\
\hline Koefisien Determinasi $\mathrm{R}^{2}$ & & 0,94 & \\
\hline Adjusted R Square & & 0,91 & \\
\hline
\end{tabular}

Nilai Adjusted $R$ square sebesar 0,91 artinya setelah disesuaikan sebesar 91,00 persen variasi konsumsi ikan laut dapat dijelaskan oleh variabel bebas yang ada di dalam model yaitu harga ikan laut, harga ikan tawar, harga ayam, harga telur, harga tempe, harga tahu, harga ikan asin, pendapatan RT, jumlah anggota rumah tangga, selera, pendidikan, dan lokasi pembelian, sedangkan sisanya sebesar 9,00 persen dijelaskan oleh variabel lain yang tidak dimasukan kedalam model. Nilai F-hitung sebesar 37,61 dengan sig. 0,00 artinya variabel harga ikan laut, harga ikan tawar, harga ayam, harga telur, harga tempe, harga tahu, harga ikan asin, pendapatan RT, jumlah anggota rumah tangga, selera, pendidikan, dan lokasi pembelian secara bersama-sama berpengaruh nyata terhadap konsumsi ikan laut dengan tingkat kepercayaan 99,00 persen.

Hasil analisis parsial faktor-faktor yang memengaruhi konsumsi ikan laut menunjukkan bahwa terdapat 7 variabel yang berpengaruh nyata yakni harga ikan laut $\left(\mathrm{X}_{1}\right)$, harga ikan tawar $\left(\mathrm{X}_{2}\right)$, harga ayam $\left(\mathrm{X}_{3}\right)$, harga tempe $\left(\mathrm{X}_{5}\right)$, pendapatan RT $\left(X_{8}\right)$, jumlah anggota keluarga $\left(X_{9}\right)$, dan pendidikan $\left(D_{1}\right)$ dengan nilai signifikan di bawah 0,10 .

Harga ikan laut $\left(\mathrm{X}_{1}\right)$ berpengaruh nyata secara negatif terhadap konsumsi ikan laut dengan tingkat kepercayaan sebesar 95,00 persen. Hasil penelitian ini sejalan dengan penelitian Putri, Zakiah dan Romano (2017) yang mengemukakan bahwa semakin meningkatnya harga suatu barang, maka 
akan menurunkan konsumsi seseorang terhadap barang tersebut.

Harga ikan tawar $\left(\mathrm{X}_{2}\right)$ berpengaruh nyata negatif terhadap konsumsi ikan laut dengan tingkat kepercayaan sebesar 95,00 persen. Semakin tinggi harga ikan tawar, maka tingkat konsumsi ikan laut akan turun. Berdasarkan informasi di lapangan, diketahui bahwa ikan tawar adalah produk komplementer dari ikan laut sebagai sumber protein, sehingga memungkinkan ibu hamil untuk mengonsumsi keduanya secara bersamaan. Transisi umur kehamilan dari trimester pertama menuju trimester kedua membuat nafsu makan ibu hamil mengalami peningkatan. Kebutuhan gizi pada masa kehamilan berbeda dengan masa sebelum hamil, peningkatan kebutuhan gizi saat hamil adalah sebesar 15,00 persen, karena dibutuhkan untuk pertumbuhan rahim, payudara, volume darah, plasenta, air ketuban dan pertumbuhan janin (Ambarwati 2012).

Harga ayam $\left(\mathrm{X}_{3}\right)$ berpengaruh nyata negatif terhadap konsumsi ikan laut dengan tingkat kepercayaan sebesar 95,00 persen. Semakin tinggi harga ayam, maka tingkat konsumsi ikan laut akan turun. Berdasarkan data dan hasil observasi di lapangan diketahui bahwa ayam merupakan produk komplementer dari ikan laut, sehingga memungkinkan ibu hamil untuk mengonsumsi keduanya secara bersamaan. Pada umur kehamilan trimester kedua dan ketiga, nafsu makan ibu sangat baik dan mudah merasa lapar. Hidangan lauk pauk hewani seperti telur, daging, ayam, ikan, hati sangat baik dan bermanfaat untuk menghindari kurang darah. Protein sebagai sumber zat pembangun dan pengatur perlu dikonsumsi lebih banyak, karena selain untuk pertumbuhan janin yang sangat pesat, juga diperlukan untuk ibu dalam persiapan persalinan (Manuaba 2008).

Harga tempe $\left(\mathrm{X}_{5}\right)$ berpengaruh nyata negatif terhadap konsumsi ikan laut dengan tingkat kepercayaan sebesar 95,00 persen. Semakin tinggi harga tempe, maka tingkat konsumsi ikan laut akan turun. Tempe adalah produk komplementer dari ikan laut sebagai sumber protein, sehingga memungkinkan responden untuk mengonsumsi keduanya secara bersamaan.

Pendapatan RT $\left(\mathrm{X}_{8}\right)$ berpengaruh nyata positif terhadap konsumsi ikan laut dengan tingkat kepercayaan sebesar 99 persen. Semakin tinggi pendapatan RT, maka tingkat konsumsi ikan laut akan naik. Riawa, Yulinda dan Darwis (2017), mengungkapkan hal serupa, yakni jumlah atau tingkat pendapatan keluarga akan meningkatkan konsumsi ikan.

Jumlah anggota keluarga $\left(\mathrm{X}_{9}\right)$ berpengaruh nyata positif terhadap konsumsi ikan laut dengan tingkat kepercayaan sebesar 99,00 persen. Semakin banyak jumlah anggota keluarga gemar makan ikan, maka tingkat konsumsi ikan laut akan naik. Berdasarkan hasil wawancara diperoleh informasi bahwa banyaknya anggota keluarga yang gemar makan ikan akan memengaruhi ibu hamil untuk ikut mengonsumsi ikan tersebut. Hal ini sejalan dengan penelitian Arthatiani, Kusnadi, dan Harianto (2018) yang mengemukakan bahwa banyaknya anggota keluarga yang gemar makan ikan serta memiliki kesadaran gizi yang tinggi akan memengaruhi anggota keluarga lainnya untuk ikut mengonsumsi, sehingga menyebabkan permintaan dan tingkat konsumsi ikan mengalami kenaikan.

Pendidikan $\left(\mathrm{D}_{1}\right)$ merupakan variabel dummy yang berpengaruh nyata positif terhadap konsumsi ikan laut dengan tingkat kepercayaan 99,00 persen, yang berarti tidak terdapat perbedaan konsumsi ikan laut antara ibu hamil yang berpendidikan tinggi dan berpendidikan rendah. Hal ini serupa dengan penelitian Parulian, Lestari dan Adawiyah (2014) yang menyatakan konsumsi seseorang akan protein hewani dipengaruhi oleh pendidikan.

Berdasarkan uji $R$ square, Adjusted $R$ square, Fhitung, uji-t serta uji masalah regresi, maka model regresi faktor-faktor yang memengaruhi konsumsi ikan laut adalah sebagai berikut:

$$
\begin{aligned}
Y= & -8,35-0,23 X_{1}-0,01 X_{2}-0,01 X_{3}-0,02 X_{4} \\
& +0,82 X_{5}+0,53 X_{6}+0,24 D_{1}+e \ldots \ldots \ldots \ldots . .(3)
\end{aligned}
$$

$$
\begin{aligned}
& \text { Keterangan : } \\
& \mathrm{Y} \quad=\text { Konsumsi ikan laut (gram protein/hari) } \\
& \mathrm{X}_{1}=\text { Harga ikan laut (Rp/gram protein) } \\
& \mathrm{X}_{2}=\text { Harga ikan tawar (Rp/gram protein) } \\
& \mathrm{X}_{3}=\text { Harga ayam (Rp/gram protein) } \\
& \mathrm{X}_{4}=\text { Harga tempe (Rp/gram protein) } \\
& \mathrm{X}_{5}=\text { Pendapatan (Rp/bulan) } \\
& \mathrm{X}_{6}=\text { Jumlah anggota keluarga (orang) } \\
& \mathrm{D}_{1}=\text { Pendidikan } \\
& \mathrm{e}
\end{aligned}
$$

\section{KESIMPULAN}

Berdasarkan hasil penelitian yang dilakukan dapat disimpulkan bahwa jenis ikan yang dikonsumsi ibu hamil adalah tongkol, layang, teri, cumi, kembung dan nibung. Rata-rata konsumsi protein hewani 
ikan laut mencapai angka 6,02 gram protein per hari. Rata-rata konsumsi energi yang berasal dari ikan laut hanya sebesar 1,40 persen atau menyumbangkan 2,70 pada skor PPH ideal untuk golongan pangan hewani. Frekuensi pembelian paling sering dilakukan satu kali dan maksimal 4 kali dalam seminggu. Lokasi pembelian ikan laut adalah pasar tradisional dan pedagang keliling. Faktor-faktor yang memengaruhi konsumsi ikan laut adalah harga ikan laut, harga ikan tawar, harga ayam, harga tempe, pendapatan, jumlah anggota keluarga, dan pendidikan.

\section{DAFTAR PUSTAKA}

Ambarwati. 2012. Gizi dan Kesehatan Reproduksi. Cakrawala Ilmu. Yogyakarta.

Arthatiani FY, Kusnadi N, dan Harianto. 2018. Analisis pola konsumsi dan model permintaan ikan menurut karakteristik rumah tangga di Indonesia. Jurnal Sosek KP, 13 (1) : 73-86. http://ejournal-balitbang.

kkp.go.id/index.php/sosek/article/download/6 967/5863. [8 Oktober 2019].

BPS [Badan Pusat Statistik] Provinsi Lampung. 2017. Produksi Perikanan Tangkap Menurut Kabupaten/Kota dan Subsektor di Provinsi Lampung. BPS Provinsi Lampung. Lampung.

DKP [Dinas Ketahanan Pangan] Kabupaten Tanggamus. 2018. Tingkat Konsumsi Ikan Laut. DKP Kabupaten Tanggamus. Kabuapten Tanggamus.

Ghozali I. 2009. Aplikasi Analisis Multivariate dengan Program SPSS. Universitas Diponegoro Press. Semarang.

Gujarati D. 2003. Ekonometrika Dasar. Erlangga. Jakarta.

Gujarati D dan Porter D. 2010. Dasar-dasar Ekonometrika Edisi Kelima. Salemba Empat. Jakarta.

Hebbeln JR. 2008. Seafood consumption, the DHA content of mothers' milk and prevalence rates of postpartumdepression' A cross-national, ecological analysis. Journal of Affective Disorder, 15 (19) : 15-29. https:// pdfs.semanticscholar.org/9321/f40a14f27b78d $7 \mathrm{~d} 2 \mathrm{f} 8 \mathrm{bd} 8 \mathrm{db} 24 \mathrm{a} 8002 \mathrm{fcee} 02$.pdf.

$[28$ November 2018].

Ismail F. 2018. Statistika untuk Penelitian Pendidikan dan Ilmu-ilmu Sosial. Prenamedia Group. Jakarta.

Margono. 2004. Metodologi Penelitian Pendidikan. PT Rineka Cipta. Jakarta.

Manuaba. 2008. Ilmu Kebidan, Penyakit Kandungan dan Keluarga Berencana. EGC. Jakarta.

Parulian J, Lestari DAH, dan Adawiyah R. 2014. Pola konsumsi daging sapi oleh rumah tangga di Bandar Lampung. JIIA, 2 (4) : 1-8. http://jurnal.fp.unila.ac.id/index.php/JIA/articl e/viewFile/991/896. [11 November 2018].

Putri AS, Zakiah, dan Romano. 2017. Analisis kepuasan dan keputusan konsumen terhadap konsumsi ikan laut di Kota Banda Aceh (studi kasus di Pasar Peunayong). Jurnal Ilmiah Mahasiswa Pertanian Unsyiah, 2 (2): 183194. http://jim.unsyiah.ac.id/JFP/article/ view/2866. [4 April 2018].

Riawa AO, Yulinda E, dan Darwis. 2016. Faktorfaktor yang mempengaruhi konsumsi masyarakat terhadap ikan segar di Kecamatan Rumbai Pesisir Pekan Baru Provinsi Riau. JOM, 44 (1) : $1-13$. https://jom.unri.ac.id/index.php/JOMFAPE IKA/article/.../13830. [4 April 2018].

Rusilanti. 2006. Menu Bergizi Untuk Ibu Hamil. Kawan Pustaka. Jakarta.

WNPG [Widyakarya Nasional Pangan dan Gizi] XI. 2018. Percepatan Penurunan Stunting Melalui Revitalisasi Ketahanan Pangan dan Gizi Dalam Rangka Mencapai Tujuan Pembangunan Berkelanjutan. LIPI. Jakarta. 